\title{
Projections of changes of areal evapotranspiration for different land-use units in the Wielkopolska Region (Poland)
}

\author{
Malgorzata Szwed ${ }^{1}$
}

Received: 1 September 2015 / Accepted: 22 July 2016 / Published online: 5 August 2016

(C) The Author(s) 2016. This article is published with open access at Springerlink.com

\begin{abstract}
Strong global warming has been observed in the last three decades. Central Europe, including Poland, is not an exception. Moreover, climate projections for Poland foresee further warming as well as changes in the quantity as well as spatial and seasonal distribution of precipitation. This will result in changes in all elements of the water balance, including the areal evapotranspiration. For estimating the areal evapotranspiration, the heat balance method (HBM) is used in this paper for the growing season (March-October), whereas for the remaining months (November-February), evaporation is calculated according to the Ivanov equation. Values of areal evapotranspiration from selected land units are examined and compared for the average conditions in two time horizons, i.e. 1961-1990 (control period) and 2061-2090 (projection horizon) over the Wielkopolska Region in Poland, based on multi-model ensemble climate projections. Projections for the future, based on the MPI-M-REMO model, indicate that the regional average increases of the annual sum of areal evapotranspiration (connected mainly with an increase of air temperature) is equal to $45 \mathrm{~mm}$, with the biggest changes during winter. In the growing season, the highest increases are expected to appear in July and June. As regards the spatial distribution, the highest increases are projected for the areas with presently highest evapotranspiration, e.g. the southwestern parts of the region.
\end{abstract}

Małgorzata Szwed

mszwed@man.poznan.pl

1 Institute for Agricultural and Forest Environment of Polish Academy of Sciences, Bukowska 19, 60-809 Poznań, Poland

\section{Background}

The water balance equation includes a component called areal evaporation (or evapotranspiration). This term has far broader meaning than the evaporation understood only as a physical process, during which liquid water turns into gas (water vapour). In natural conditions, water returns to the atmosphere as a result of many processes and in different ways. Evaporation understood as a physical process is only one of them. The basic elements of the areal evapotranspiration are as follows: evaporation from the soil and evaporation from the wet surface of plants and other wet structures, transpiration of plants and evaporation from open water surfaces (lakes, rivers, ponds, etc.).

The areal evapotranspiration - being a subject of this research - is driven by thermal and humidity conditions. The globally averaged combined land and ocean surface temperature data as calculated by a linear trend, show a warming of 0.85 (0.65 to 1.06 ) ${ }^{\circ} \mathrm{C}$, over the period 1880 to 2012 , when multiple independently produced datasets exist (cf. IPCC 2013). Observations and climate model simulations indicate an acceleration of the water cycle, with possible consequences to extremes (Wetherald and Manabe 2002, Huntington 2006). Therefore, global warming will result in changes in all elements of the water balance, including the areal evapotranspiration, which will have impact on the biosphere. On the other hand, the environment influenced by man to various degrees (mainly via changes of the land-use structure) affects elements of the climate system. The intense growth of industry in the nineteenth century together with the increasing exploitation and use of the environmental resources contributed to large, often irreversible, changes in the environment. However, it was mainly agriculture that led to huge areal changes in land use and land cover. With the intensification of the agricultural production (triggered by the growth of the human population), 
the pressure on the environment increased. The agriculture does not only occupy gigantic areas but also strongly affects all elements of the environment.

This is because heat balance (and indirectly water balance) structure of every active surface depends on the land-use and land-cover structure (Olejnik 1996, Leśny 1998, Kędziora 1999, Eulenstein et al. 2005). Hence, land-use changes (clear cutting of forests, changes of the structure of sowings, processes of irrigating or draining large areas, etc.) cause a change of components of the heat balance which results in changes of transfer of energy and matter in the landscape, and changes of the relation between heat and water balances in the landscape (Persson 1997, Gustafsson et al. 2004, Czarnecka et al. 2009). Therefore, a crucial statement for this study is that the heat balance structure does not only depend on meteorological conditions but also on many environmental factors, mainly plant characteristics (type of plant cover, plant development stage and their conditions). Flow of water in the ecosystem, and particularly in plants, determines their development and indicates intensity of biological processes (Grelle et al. 1999, Mo and Liu 2001, Kar and Kumar 2007). The influence of the weather conditions on the heat balance structure is essential, but it plays only a modifying role. The weather condition could mitigate or deepen differences in the heat balance structure between biologically active and inactive surface. The differences become more considerable as radiation and wind grow stronger and cloudiness and humidity in the environment decrease (Leśny and Juszczak 2005a).

The main objective of this research is to determine differences in evapotranspiration from various active surfaces and their projected change in the changing climate. Another purpose of this study is to reveal whether, and to what extent, the climate change will influence changes of areal evapotranspiration in Wielkopolska Region in general and from individual land-use surfaces. Another question the study will try to answer is whether the projected climate change has a comparable influence on changes in areal evapotranspiration as the changes resulting from possible modifications of land use. Therefore, in this study, the areal evapotranspiration for the average conditions in two time horizons, i.e. in the control period (19611990) and in the future projection horizon (2061-2090), is examined and compared for the Wielkopolska Region, Poland (Fig. 1), based on ENSEMBLES climate models.

The Wielkopolska Region is a historical province located in central and western Poland, in the Wielkopolska Lake District and the South Wielkopolska Lowland, in the river basin of the lower and middle Warta. The Wielkopolska Region remains under the influence of oceanic air masses that are responsible for the relative mildness of the climate. The further east the more noticeable is the influence of continental climate. The average annual temperature is $+8.2{ }^{\circ} \mathrm{C}$, and varies from $+7.6{ }^{\circ} \mathrm{C}$ in the north to $+8.5{ }^{\circ} \mathrm{C}$ in the south and west. Even though annual precipitation of the Wielkopolska

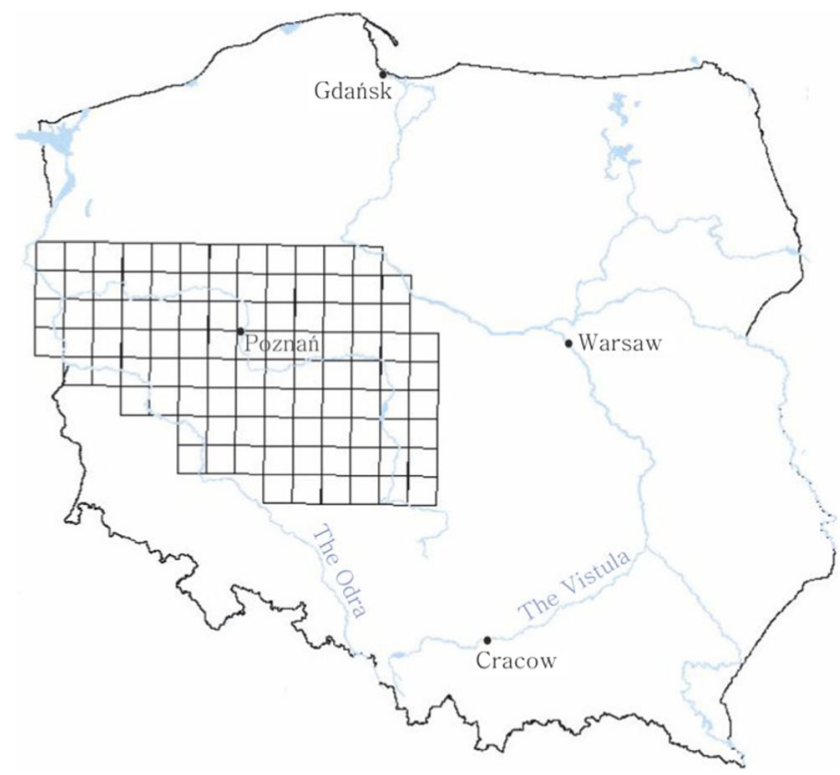

Fig. 1 The studied grid-cells over the Wielkopolska Region (Poland)

Region is among the lowest in Poland (less than $600 \mathrm{~mm}$ in most areas), it is enough to cover the demand for the evaporation and the total outflow. However, such a statement is true only for an average climatic year. Generally, in wet years, only autumn precipitation occurring after the end of vegetation growth creates a distinct surplus of water in the environment, while in dry years, the year ends with the deficit. Within individual seasons (most often during the growing season) and individual years, the situation can be more complicated and some of the areas in the Wielkopolska Region are characterised by considerable and long-term water deficits. It is particularly severe in the western and northwestern parts of the region (Jokiel 2004).

The Wielkopolska Region is definitely the most important agricultural region in Poland. Although its natural conditions (climate, soil) are about average in the country, and in some areas even poorer than average, the level of agriculture in this region has traditionally been higher than the national average. The agricultural lands in the Wielkopolska Region occupy about $60 \%$ of the area (of which the arable area covers about $82 \%$, orchards - about $0.6 \%$, grasslands-about $8 \%$, etc.). Forests occupy around $26 \%$ of the area (UStat Poznan 2013). The general land-use structure is presented in Fig. 2 based on the Corine Land Cover 2000 (EEA 2000).

\section{Data}

In this study, time series of 10-day values of areal evapotranspiration for eight land-use units, namely coniferous and deciduous forests, arable lands (including cereal and root crops), meadows, wastelands, water bodies and urban areas, are examined for the average conditions in two time horizons, i.e. 


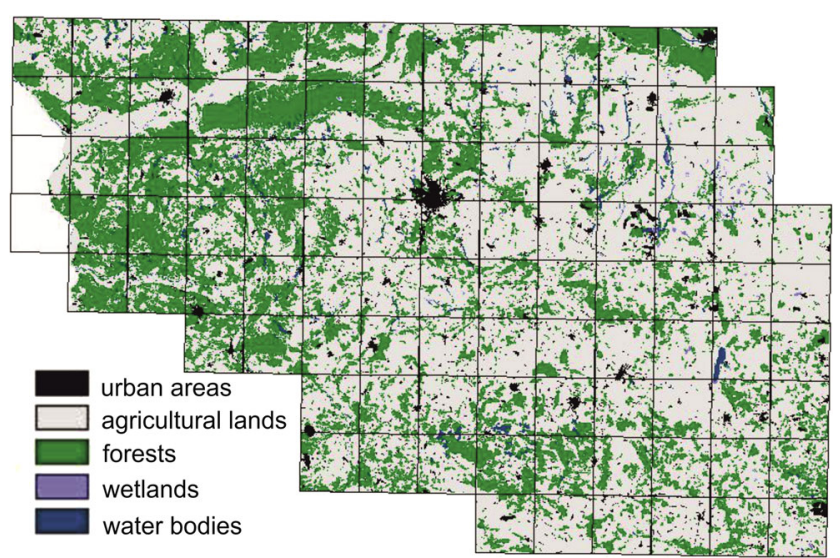

Fig. 2 The land-use structure in the Wielkopolska Region based on the CLC2000 (EEA 2000)

1961-1990 (control period) and 2061-2090 (projection horizon) over the Wielkopolska Region.

Series of present and future evapotranspiration values in the Wielkopolska Region are evaluated, based on multimodel ensemble climate projections obtained within the ENSEMBLES Project of the 6th Framework Programme of the EU. The main calculations are based on the simulation results of daily temperature, relative humidity and wind speed from five ENSEMBLES regional climate models for 100 grid cells in the Wielkopolska Region (Fig. 1).

The regional models from the ENSEMBLES Project used in this study are as follows, in alphabetical order: C4IRCA3 from the Rossby Centre (Norrköping, Sweden), CLM from the ETH (Zurich, Switzerland), KNMI-RACMO2 from the Royal National Meteorological Institute (de Bilt, the Netherlands), METO-HC from the Met Office's Hadley Centre (Exeter, UK) and MPI-M-REMO from the Max Planck Institute (Hamburg, Germany) (Van der Linden and Mitchell, 2009). Regional climatic models were generated, based on two different global circulation models (GCMs). Regional models C4IRCA3, ETHZ-CLM and METO-HC are based on the global model METO-HC standard, while models MPI-M-REMO and KNMI-RACMO2 are calibrated based on the global circulation model ECHAM of the fifth generation. All of the used ENSEMBLES regional climate models cover Europe with a spatial resolution of about 25 by $25 \mathrm{~km}$ and draw just one possible future, corresponding to a specific SRES emission scenario, A1B (IPCC 2000).

\section{Methods}

Different methods have been used in numerous studies/papers to solve evaporation research questions (e.g. Rahimikhoob 2010; Barella-Ortiz et al. 2013; Minderlein and Menzel 2015). In this paper, the heat balance method (HBM) was used for estimating the areal evapotranspiration during the growing season (March-October), whereas for the remaining months (November-February), evaporation was calculated according to the Ivanov equation.

The studies on the daily and seasonal variability of the evapotranspiration process conducted there showed that the most important factors deciding on its intensity are the amount of available energy (the element driving the process of evaporation), the amount of available water (the flow from the soil, through plants, to the atmosphere is its essence) as well as the effectiveness of transpiring apparatus which dictates the effectiveness of using the available energy in the evapotranspiration process (cf. Olejnik et al. 1999, 2000). Therefore, intensity of evapotranspiration depends on the value of net radiation $\left(R_{\mathrm{n}}\right)$, on the water storage in the soil, on the height and intensity of precipitation, and on the development stage of plants which determine their ability to use water for transpiration. Long-term field studies conducted by the Department of Agrometeorology of the Poznan University of Life Sciences resulted in development of the HBM method for the estimation of values of areal evapotranspiration for different land-use units in the growing season, March-October (Olejnik and Kędziora 1991). Series of measurements of the heat balance structure of different surfaces were conducted in 1980s-1990s. This method was developed for the purpose of estimating heat balance components based on standard meteorological data (mean temperature, wind speed, plant development stage and land-use conditions).

The HBM method allows evaluating the real evapotranspiration based on the quantity of energy which comes from the Sun to the Earth-atmosphere system. This energy is determined through the irradiation to the horizontal surface on the atmosphere border. The HBM starts from the energy balance equation.

$R_{n}+\mathrm{LE}+A+G=0$

where $R_{\mathrm{n}}$ is the net radiation, $\mathrm{LE}$ is the latent heat flux, $A$ is the sensible heat flux, and $G$ is the soil heat flux. All the heat balance components are expressed in mega joules per square metre and given period $\left(\mathrm{MJ} \mathrm{m}^{-2}\right.$ period $\left.^{-1}\right)$ or in watts per square metre and given period $\left(\mathrm{W} \mathrm{m}^{-2}\right.$ period $\left.^{-1}\right)$. All fluxes towards the active surface are taken as positive while the outgoing fluxes are assumed negative.

$R_{\mathrm{n}}$ has been assessed based on the Black and Brunt equation.

$$
\begin{aligned}
R_{n}= & (1-\alpha) \cdot R_{o} \cdot(0.22+0.54 \cdot u)-5.68 \cdot 10^{-8} \cdot(t+273)^{4} \\
& \cdot\left(0.56-0.08 \cdot e^{0.5}\right) \cdot(0.10+0.90 \cdot u)
\end{aligned}
$$

where $\alpha$ is the albedo (dimensionless), $R_{\mathrm{o}}$ is the extra terrestrial solar radiation $\left(\mathrm{W} \mathrm{m}^{-2}\right), u$ is the relative sunshine (dimensionless), $t$ is the air temperature $\left({ }^{\circ} \mathrm{C}\right)$ and $e$ is the water vapour pressure (hPa). 
Albedo for field crops and meadows $(\alpha)$ was calculated as follows: $a=0.16+0.07 \cdot f$, where $f$ is the plant development stage, changing from 0 (bare soil) to 1 (full development plant cover). For water, the value of albedo was taken as 0.10 , while for urban areas as 0.30 . For forests, albedo was taken as 0.16 (averaged for coniferous and deciduous forests).

The $G$ values in the vegetative season were appointed based on Kędziora's formula (1999).

$G=-0.2 R_{n} \cdot(1-0.75 f) \cdot \sin \left[\frac{\pi}{6}(i-2)\right]$

where $i$ denotes the ordinal number of the respective month and $f$ is the plant development stage (dimensionless), changing from 0 to 1 .

Flux of the energy used for the evaporation of water (LE) was determined using the agrometeorological empirical index $(W)$ expressing the influence of the meteorological conditions and plant development stage on evapotranspiration (the higher the index value is, the greater the part of net radiation used for evapotranspiration) and equation estimating the Bowen ratio $(\beta)$. The equations that have been used take the following form:

$W=\frac{100\left(d \cdot v^{0.5}\right)^{\operatorname{art}\left(\frac{\pi}{2} \cdot f\right)}}{t(u+0.4)}$

where $d$ is the saturation vapour pressure deficit $(\mathrm{hPa}), v$ is the wind speed $\left(\mathrm{m} \mathrm{s}^{-1}\right)$ and $t$ is the air temperature $\left({ }^{\circ} \mathrm{C}\right)$.

$\beta=12.75 /(W+3.9)-0.02$

$\mathrm{LE}=-\frac{\left(R_{n}+G\right)}{(1+\beta)}$

$A=-(R \mathrm{n}+\mathrm{LE}+G)$

All calculations were done for $24 \mathrm{~h}$ mean in the given 10 day period. So, a $24 \mathrm{~h}$ LE average value was calculated. In further research, the latent heat flux was converted into the real evapotranspiration. It is possible to convert the $24 \mathrm{~h} \mathrm{LE}$ flux into the value of the daily real evapotranspiration $(\mathrm{mm})$ using the formula $E=\mathrm{LE} / 28.34$. In case of this research, values of 10-day evapotranspiration were examined. So, daily value of $E$ was multiplied by 10 (number of days). This methodology was described in detail by Olejnik and Kędziora (1991).

The HBM has often been tested and used in Polish conditions, especially in the Wielkopolska Region. In the research of Leśny (2011), the 10-day values of evapotranspiration estimated from HBM model were compared with the measured values (experimental method). In the period from May to September, the differences between the value of evaporation both measured and estimated by the model did not exceed $10 \%$. The differences were the smallest when plants did not undergo any stress related to water shortage, while during the water shortage conditions, the model overestimated evaporation. It means that the HBM can be successfully applied for estimating the areal evapotranspiration in the growing season (Leśny 2011) and for estimating the climate water balance in the region (Kędziora et al. 1989, Leśny and Juszczak 2004, 2005b, Musiał et al. 2007).

In this paper, eight types of land-use units are taken into account. As to the plant, the plant development is described by the so-called developmental stage. As a rule, it is determined in a descriptive way, which makes it impossible to use such a parameter in the modelling of processes occurring in the environment. In this study, the degree of plant development is represented by a numerical value from 0 (zero) to 1 (one), where 0 means the lack of plants, and 1 means that plants are in the highest biological activity, reaching a maximum capacity to use water for transpiration. The classification of plant development stages follows Kędziora (Table 1).

Beyond the growing season (November-February), the values of evaporation $(E)$ were calculated based on the Ivanov equation (1954) valid for monthly values, i.e.

$E=0.0018 \cdot(T+25)^{2} \cdot(100-\mathrm{Rh})$

where $T$ is the air temperature and $\mathrm{Rh}$ is the relative humidity (Filimonova and Trubetskova 2005). Calculating evaporation with the use of empirical methods for the cool periods cannot include models equations based on energy characteristics of the surface, because atmospheric evaporation capacity determines the evaporation. In the humid temperate climate, it is illustrated by the Ivanov formula. It is also assumed that biological activity of plants does not occur in the cool period, and therefore, values of the evaporation are equal for every analysed land-use units.

Siedlecki et al. (2012) estimated monthly sums of the evaporation using the method of eddy covariance and empirical formulas (by Schmuck, Ivanov, Bac and Tichomirov) for the city of Łódź. The achieved results show the high divergence between values of evaporation calculated with various methods. The values obtained with the help of empirical methods are higher that the values from eddy covariance, yet the smallest differences are noticed in the cool half-year. Therefore, Siedlecki et al. (2012) conclude that applying empirical methods in the summer period can lead to incorrect results.

In order to finally calculate the areal evapotranspiration in the area of each grid-cell, one must know the land-use structure. This work uses information included in both Corine Land Cover 2000 and statistical yearbooks for Poland. Additionally, some assumptions generalising the structure have been made. Only the area of dominating crops in the region has been taken into account. It has been assumed that the structure of agricultural land consists of $70 \%$ of the cereal 
Table 1 Index of plant development stages, following Kędziora

\begin{tabular}{|c|c|c|c|c|c|c|c|c|}
\hline $\begin{array}{l}\text { No. of } \\
\text { 10-day } \\
\text { period }\end{array}$ & $\begin{array}{l}\text { Water } \\
\text { bodies }\end{array}$ & $\begin{array}{l}\text { Deciduous } \\
\text { forests }\end{array}$ & $\begin{array}{l}\text { Coniferous } \\
\text { forests }\end{array}$ & $\begin{array}{l}\text { Cereal } \\
\text { crops }\end{array}$ & $\begin{array}{l}\text { Root } \\
\text { crops }\end{array}$ & Meadows & Wastelands & $\begin{array}{l}\text { Urban } \\
\text { areas }\end{array}$ \\
\hline 7 & 0.90 & 0.10 & 0.28 & 0.13 & 0.02 & 0.04 & 0.01 & 0.02 \\
\hline 8 & 0.90 & 0.10 & 0.28 & 0.15 & 0.02 & 0.09 & 0.01 & 0.02 \\
\hline 9 & 0.90 & 0.10 & 0.28 & 0.17 & 0.02 & 0.13 & 0.01 & 0.02 \\
\hline 10 & 0.90 & 0.10 & 0.28 & 0.20 & 0.02 & 0.18 & 0.01 & 0.02 \\
\hline 11 & 0.90 & 0.12 & 0.50 & 0.30 & 0.02 & 0.26 & 0.01 & 0.02 \\
\hline 12 & 0.90 & 0.29 & 0.80 & 0.42 & 0.02 & 0.35 & 0.01 & 0.02 \\
\hline 13 & 0.90 & 0.63 & 1.00 & 0.60 & 0.02 & 0.47 & 0.01 & 0.02 \\
\hline 14 & 0.90 & 0.92 & 1.00 & 0.80 & 0.02 & 0.61 & 0.01 & 0.02 \\
\hline 15 & 0.90 & 1.00 & 1.00 & 0.93 & 0.02 & 0.77 & 0.01 & 0.02 \\
\hline 16 & 0.90 & 1.00 & 1.00 & 0.98 & 0.10 & 0.93 & 0.01 & 0.02 \\
\hline 17 & 0.90 & 1.00 & 1.00 & 1.00 & 0.40 & 1.00 & 0.01 & 0.02 \\
\hline 18 & 0.90 & 1.00 & 1.00 & 1.00 & 0.80 & 0.65 & 0.01 & 0.02 \\
\hline 19 & 0.90 & 1.00 & 1.00 & 1.00 & 0.95 & 0.04 & 0.01 & 0.02 \\
\hline 20 & 0.90 & 1.00 & 1.00 & 1.00 & 1.00 & 0.29 & 0.01 & 0.02 \\
\hline 21 & 0.90 & 1.00 & 1.00 & 0.70 & 1.00 & 0.53 & 0.01 & 0.02 \\
\hline 22 & 0.90 & 1.00 & 1.00 & 0.02 & 1.00 & 0.77 & 0.01 & 0.02 \\
\hline 23 & 0.90 & 1.00 & 1.00 & 0.02 & 1.00 & 0.91 & 0.01 & 0.02 \\
\hline 24 & 0.90 & 1.00 & 1.00 & 0.02 & 1.00 & 1.00 & 0.01 & 0.02 \\
\hline 25 & 0.90 & 1.00 & 1.00 & 0.02 & 1.00 & 0.47 & 0.01 & 0.02 \\
\hline 26 & 0.90 & 1.00 & 1.00 & 0.02 & 1.00 & 0.08 & 0.01 & 0.02 \\
\hline 27 & 0.90 & 1.00 & 1.00 & 0.04 & 1.00 & 0.15 & 0.01 & 0.02 \\
\hline 28 & 0.90 & 0.72 & 0.65 & 0.08 & 0.95 & 0.22 & 0.01 & 0.02 \\
\hline 29 & 0.90 & 0.38 & 0.36 & 0.12 & 0.90 & 0.28 & 0.01 & 0.02 \\
\hline 30 & 0.90 & 0.10 & 0.30 & 0.17 & 0.80 & 0.34 & 0.01 & 0.02 \\
\hline
\end{tabular}

crop, $20 \%$ of root plants and $10 \%$ of grasslands. Additionally, forests, wasteland, urbanised areas and waters (with wetlands) have been taken into consideration.

\section{Verification of the models}

This research directly uses daily values of air temperature, relative humidity and wind speed from five ENSEMBLES regional climate models. For the wind speed, the correction from height of $10 \mathrm{~m}$ as delivered in the model to height of $2 \mathrm{~m}$ was applied. Bias correction was not applied.

Temperature is the most essential of the values which can be verified. In this paper, the author used quasi-validation of temperature conducted earlier (Szwed et al. 2010), where for the time horizon 1961-1990, model-based simulations was compared with reanalysis information and with data from observation stations on the ground. Values of the relative humidity and the wind speed were not verified because of the lack of the real data in the author's datasets. However, based on widely available average values for Poland, it is possible to come to the conclusion that both values, humidity and the wind speeds, are overestimated.
Additionally, the author used also quasi-validation of precipitation from Szwed et al. (2010), even though these values are not necessary for the purposes of this research. However, the results of this research could be useful - in the more distant perspective-for studies of the climatic water balance in the region, and then the proper distribution of precipitation within 1 year is crucial for undertaken examinations. Therefore, validation of precipitation also affected the evaluation of the model.

The degree of consistency between modelled and observed values varies between models and is location specific. Generally, the ENSEMBLES models are reasonably successful in mimicking the observed distribution of mean temperature and seasonal cycles of temperature in Poland, yet the values from the models are overestimated. Based on secondorder statistics, the MPI-M-REMO and METO-HC models simulate the temperature in the reference period 1961-1990, a little more precisely than the other models. When it comes to precipitation, agreement between models for the control period of 1961-1990 is not satisfactory. For describing distribution of precipitation during the year, the MPI model is the best option (Fig. 3). 


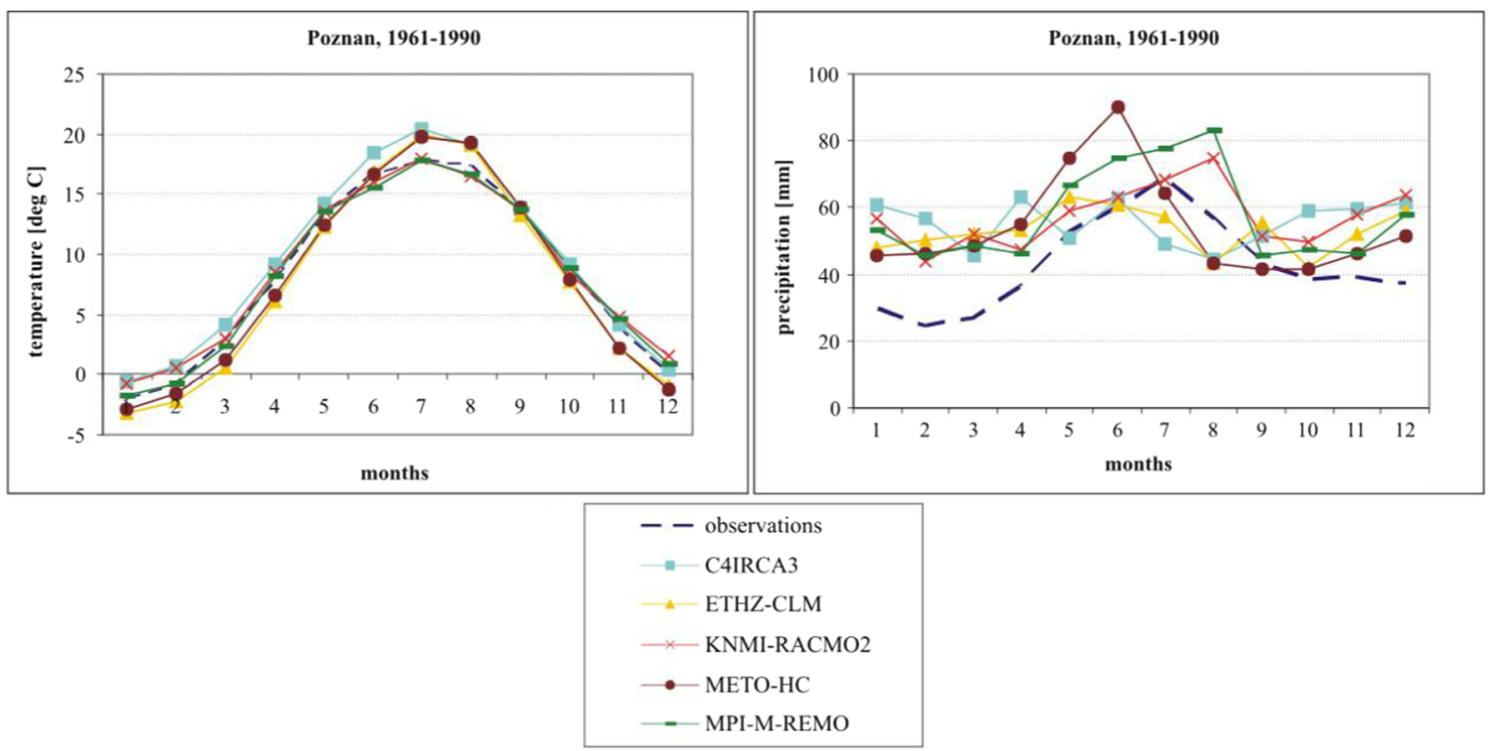

Fig. 3 The mean monthly temperature and precipitation based on the observation data for the city of Poznan and on the climate model simulations (mean values for the grid-cells around Poznan) for the control period

To sum up, the outcome of the verification of models for the territory of Poland indicates the MPI-M-REMO model as "the best" for both temperature and precipitation conditions, and results obtained with the help of this model are presented in this paper in more detail. Nevertheless, based on an ensemble of models, a broader possible range of uncertainty, resulting from model disagreement, is also presented in this paper.

\section{Changes in annual evapotranspiration}

As expected, out of the analysed land-use units, the highest values of evaporation are estimated for water bodies. In this case, shortage of water for evaporation does not occur. However, it should be remembered that supporting the process of evaporation requires certain conditions: availability of water, water vapour pressure deficit, energy needed for the water to change its phase as well as energy for transporting vapour from the evaporating surface. If the air over the evaporating surface is in stillness, the saturation point is quickly achieved and evaporation stops. However, change of these meteorological parameters in the model is equal for all units.
The MPI-M-REMO model estimates that, at present, the average annual evaporation from water bodies in the Wielkopolska Region varies from 753 to $797 \mathrm{~mm}$ (with the average value of $774 \mathrm{~mm}$ ) (Table 2). Projections for the future indicate an increase of evaporation. In the future horizon 2061-2090, these values will be higher, on average by $55 \mathrm{~mm}$; in addition, a range of values will be broader, because the maximum values will rise more than the minima (Table 3). For comparison, based on methods of Penman and Ivanov, Jankowiak and Kedziora (2009) estimated the annual values of evaporation from the open water surface in the Wielkopolska Region in the period of 1996-2006. According to their result, the annual totals vary from 600 to $1000 \mathrm{~mm}$.

The spatial distribution of evaporation from water bodies shows that, at present, the lowest values are estimated for the northern parts of the region (ice-marginal valley of the river Warta) and the highest for the southwest (in the Barycz Valley). Projections with the help of the MPI-M-REMO model indicate the smallest increases of evaporation in the north and the northeast of the region and definitely the highest increases in the southwestern parts of the region (Fig. 4). (Note: The convention applied to the figures in this and the next chapter is that the value of evaporation in an individual grid-

Table 2 The annual sums of evapotranspiration $(\mathrm{mm})$ for different land-use units for the control period 1961-1990 and (in brackets) the increases of the annual evapotranspiration ( $\mathrm{mm}$ ) in the future (2061-2090), based on the MPI-M-REMO model

\begin{tabular}{|c|c|c|c|c|c|c|c|c|}
\hline & Water bodies & Deciduous forests & Conifeous forests & Cereal crops & Root crops & Meadows & Wastelands & $\begin{array}{l}\text { Urban } \\
\text { areas }\end{array}$ \\
\hline Min & $753(43)$ & $628(40)$ & $688(42)$ & $536(31)$ & $525(35)$ & $492(30)$ & $396(17)$ & $323(21)$ \\
\hline Average & $774(55)$ & $646(51)$ & $708(53)$ & $552(42)$ & $542(46)$ & $508(42)$ & $410(27)$ & $338(32)$ \\
\hline Max & $797(68)$ & $670(64)$ & $731(66)$ & $576(55)$ & $568(59)$ & $533(54)$ & $435(40)$ & $365(44)$ \\
\hline
\end{tabular}


Table 3 The annual sums of evaporation (mm) from water bodies for the control period 1961-1990 and (in brackets) the increases of the annual evaporation $(\mathrm{mm})$ in the future (2061-2090), based on different models

\begin{tabular}{lllllll}
\hline & MPI-M-REMO & METO-HC & KNMI-RACMO2 & ETHZ-CLM & C4IRCA3 & Average model \\
\hline Min & $753(43)$ & $740(68)$ & $767(27)$ & $718(26)$ & $774(29)$ & $753(42)$ \\
Average & $774(55)$ & $751(78)$ & $783(36)$ & $741(31)$ & $809(38)$ & $772(48)$ \\
Max & $797(68)$ & $762(87)$ & $796(40)$ & $767(36)$ & $822(43)$ & $783(54)$ \\
\hline
\end{tabular}

cell corresponds to one specific land-use unit dominating in this grid-cell, that is, changes of the value of evapotranspiration between individual cells depend solely on climatic conditions.)

For the water bodies, the mean value of evaporation obtained from five climatic models used in this study is close to the value resulting from the MPI-M-REMO model. The spatial distribution of present sums of evaporation gives also a similar picture to the one from the MPI-M-REMO model; however, minimum values of evaporation are moved to the centre of the region. The spatial distribution of projected increases of evaporation is even more in line with the results from the MPI-MREMO model (see Fig. 4). Yet, individual models differ significantly. The lowest values of evaporation result from the ETHZ-CLM model, while the C4IRCA3 model overestimates these values the most. Next, the smallest spatial diversity in the region is given by the METO-HC model, while for the ETHZ-CLM, the diversity is greatest (Table 3).

Out of all plant communities analysed in this paper, forests, particularly coniferous forests, are characterised by the highest evapotranspiration (Tables 2 and 4). Coniferous forests are evergreen (i.e. biologically active all the year round). It is assumed that transpiration apparatus of trees remains at the same level of activity for the entire growing season. In calculations with the HBM model, it results in the highest value of evapotranspiration within all types of cultivations. The high vegetative activity of every forest results also from its biodiversity. The forests consist of many species of plants, and when some plants are finishing or limiting their vegetative processes, others continue or enter the period of intense growth.

The annual sums of evapotranspiration from coniferous forest based on the MPI-M-REMO model vary from 688 to $731 \mathrm{~mm}$ (with the average value for the region of $708 \mathrm{~mm}$ ). Projections for the future indicate increases of the evapotranspiration, on average by $53 \mathrm{~mm}$ (Table 2). Annual sums of evapotranspiration from coniferous forest, calculated as the mean value from five models, vary from 689 to $717 \mathrm{~mm}$. The mean value for the region is $706 \mathrm{~mm}$. All the models project future increases of evapotranspiration from forest areas. The values of increases are similar to the value for the MPI-M-REMO model, which for coniferous forest is $46 \mathrm{~mm}$ (Table 4).

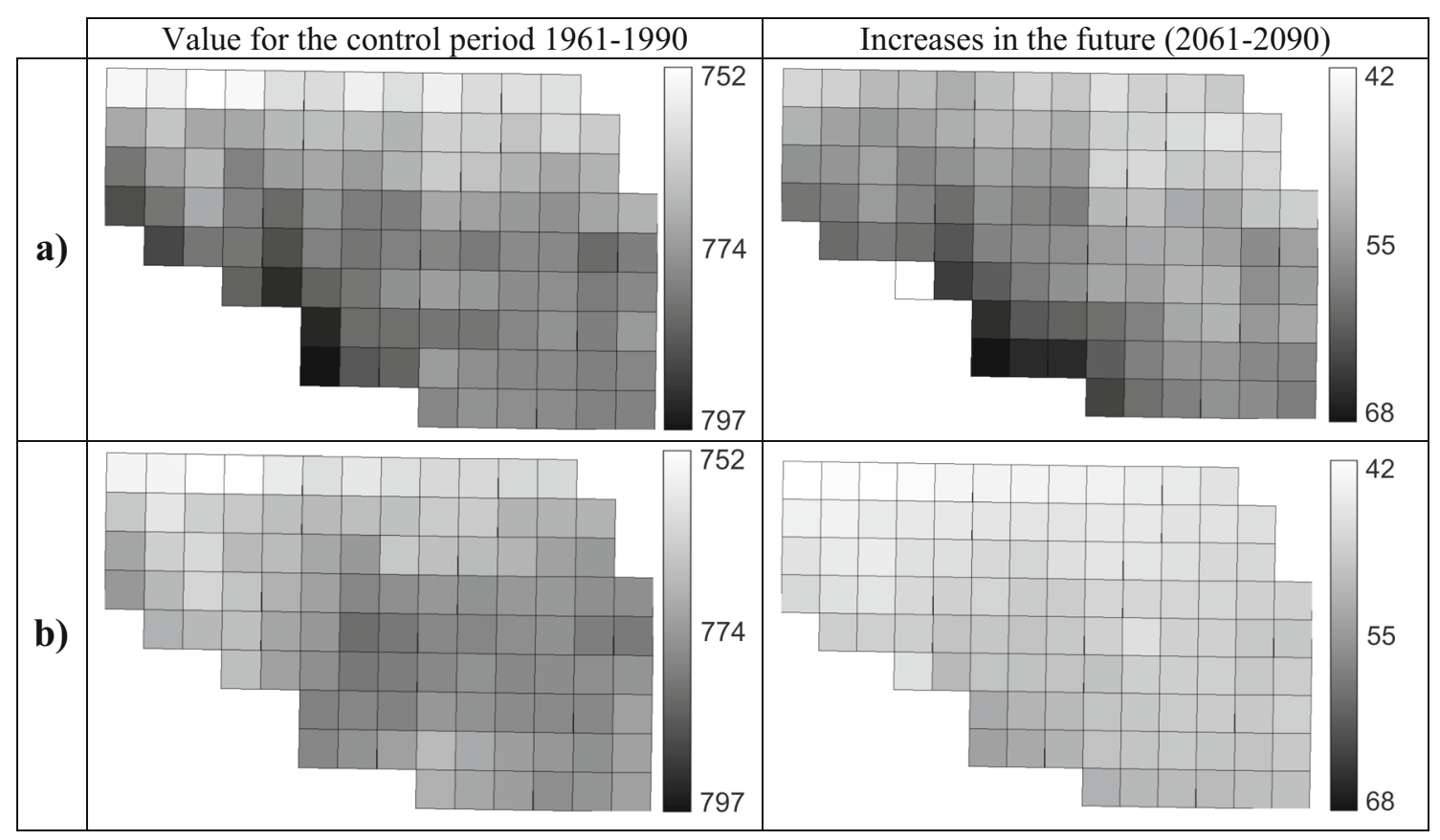

Fig. 4 The annual values of evaporation ( $\mathrm{mm}$ ) from water bodies for the control period (1961-1990) and the increases of the annual evaporation (mm) in the future (2061-2090), based on the a MPI-M-REMO model and $\mathbf{b}$ the average value from five models 
Table 4 The annual sums of evapotranspiration ( $\mathrm{mm}$ ) for different land-use units for the control period 1961-1990 and (in brackets) the increases of the annual evapotranspiration $(\mathrm{mm})$ in the future (2061-2090), the mean value from five models

\begin{tabular}{lllllllll}
\hline & Water bodies & Deciduous forests & Conifeous forests & Cereal crops & Root crops & Meadows & Wastelands & Urban areas \\
\hline Min & $753(42)$ & $629(38)$ & $689(40)$ & $538(27)$ & $529(31)$ & $494(25)$ & $401(8)$ & $329(14)$ \\
Average & $772(48)$ & $646(44)$ & $706(46)$ & $552(31)$ & $543(36)$ & $507(30)$ & $410(13)$ & $338(18)$ \\
Max & $783(54)$ & $655(50)$ & $717(52)$ & $562(38)$ & $556(43)$ & $518(36)$ & $423(19)$ & $353(24)$ \\
\hline
\end{tabular}

As to the spatial distribution of evapotranspiration from forest communities in the Wielkopolska Region, according to all models, at present (for the control period of 19611990) forests from the northern part of the region are characterised by the lowest values of evapotranspiration, while the highest values are typical for forests located in the southwest of the region (MPI-M-REMO model) or in the southern and central parts (average from five models). Projections with the help of the MPI-M-REMO model and of an "average" model indicate the smallest increases of areal evapotranspiration in the north and the northeast of the region (on average less than $45 \mathrm{~mm}$ ) and definitely the highest increases (more than $60 \mathrm{~mm}$ for the MPI-M-REMO model and more than 50 for an "average" model) in the southwestern parts of the region (Fig. 5).

The spatial distribution of annual sums of evapotranspiration and their increases in the future for deciduous forests resemble the spatial distribution for coniferous forests, but they attain lower values. The average annual sum of evapotranspiration is about $50 \mathrm{~mm}$ lower while the average increase of less than $5 \mathrm{~mm}$ (Tables 2 and 4).

At present, the annual evapotranspiration from agricultural lands is about $550 \mathrm{~mm}$ (with the highest values for cereal crops). There is a considerable similarity between the MPIM-REMO model and the average values from the five models of annual values of evapotranspiration in the Wielkopolska Region. The projections of future increases of evapotranspiration are not very similar between models. Annual increases of evapotranspiration for agricultural areas are projected to be greater than $40 \mathrm{~mm}$ (for the MPI-M-REMO model) and $30 \mathrm{~mm}$ (average value for five models) with the highest value for the root crops (46 $\mathrm{mm}$ in the MPI-M-REMO model and $36 \mathrm{~mm}$ in the "average" model) (Tables 2 and 4). As to the spatial variability of future increases, based on MPI-MREMO model, the highest changes of evapotranspiration are projected for the southeastern part of the region, while for the "average" model the highest increases are spread over the central part (see Fig. 6).

\section{Changes in seasonal evapotranspiration}

Distribution of the areal evapotranspiration in an average year was determined based on the MPI-M-REMO model, as it reflects seasonal variability of precipitation better than other models do.

Analysis of the example of water bodies shows that the highest monthly values of evaporation (over $140 \mathrm{~mm}$ ) are recorded in June and July. The sum of evaporation for three summer months (JJA) exceeds half of the annual sum of evaporation. For the wastelands the temporal variability of evaporation is similar, with the highest monthly values also in June and July-about $60 \mathrm{~mm}$ (Table 5).

For comparison, empirical formulas (developed for open water surface in fact), used by Siedlecki et al. (2012) gave results of about 70 to $140 \mathrm{~mm}$ monthly evaporation in the summer period; the values were the highest in July and reached maximum values up to $225 \mathrm{~mm}$ in the southwest of the region.

Differences in the annual distribution of evapotranspiration of different plants/crops result from the different courses of plant vegetation. Up to the 12 th decade of the year - the turn a)

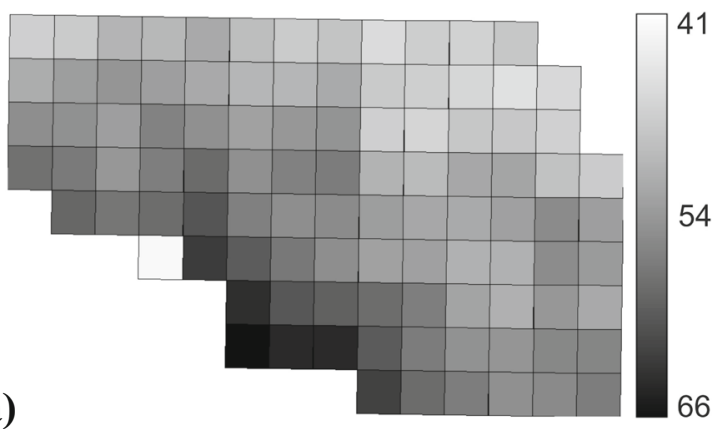

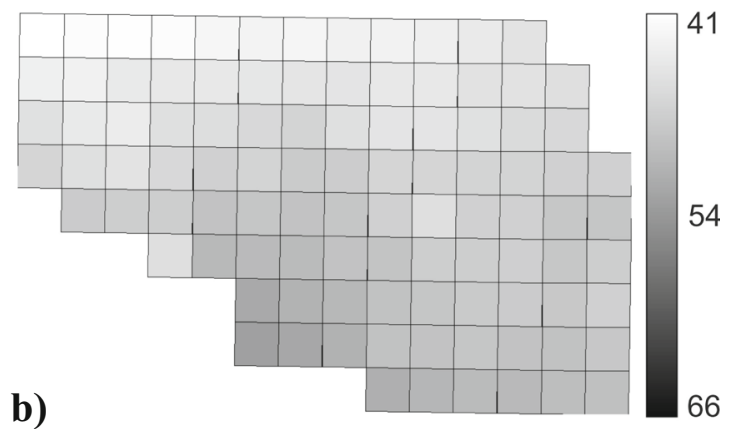

6

Fig. 5 The increases of the annual areal evapotranspiration $(\mathrm{mm})$ in the future (2061-2090) from coniferous forests based on a MPI-M-REMO model and $\mathbf{b}$ the average value from five models 

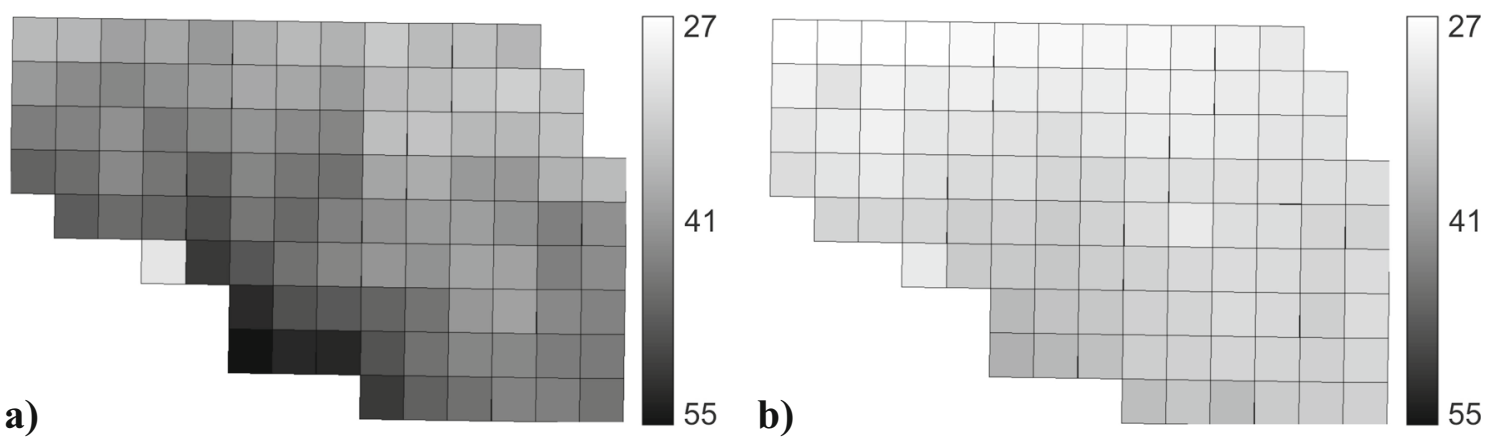

Fig. 6 The increases of the annual areal evapotranspiration $(\mathrm{mm})$ in the future (2061-2090) from cereal crops based on a MPI-M-REMO model and b the average value from five models

on March and April - evapotranspiration of all areas is almost the same, because there are no plants or they are still inactive. Minor differences result from various values of albedo for different surfaces. From the 13th decade, larger differences appear and they last up to the end of June or the beginning of July (between 18th and 20th decade), that is to the point when developmental phases of all plants equalise. In an average year, the strongest divergences in areal evapotranspiration value begin in mid July, depending whether the plant is already going into the rest period (or phase after cropping) or it is still developing.

Coniferous forests, even though they are evergreen, are also subject to natural cycles of growing and ageing. However, it is assumed that the transpiration apparatus of the coniferous trees remains on the same level of activity for the entire growing season and is ready for the transpiration earlier than the apparatus of deciduous plants. In calculations with the HBM model, it results in the highest value of evapotranspiration among all types of cultivation. Similarly, the deciduous forest very quickly achieves the maximum value of the developmental phase and keeps this value for almost all the growing season. Therefore the distribution of evapotranspiration of the deciduous forest for the entire season continues on a very high level, limited most notably by meteorological conditions. It results from the persistence of the vegetative activity of the forest. The highest monthly values - about or above $120 \mathrm{~mm}$ - are estimated for June and July (Table 5).
As regards cultivations, the course of the development of the winter crops begins very early. Their sudden growth starts usually in May and quickly reaches a maximum transpiration capacity. In literature, it is assumed that this stage continues to the harvest time. Therefore, the highest values of the monthly evapotranspiration from cereal crops appear already in June $(110 \mathrm{~mm})$. The development of root crops begins much later. For example, beets are usually planted in April, and they reach a physiological maturity in July and August (with maximum of the transpiration ability). Harvest takes place up to the end of September and in October, which affects the extended growth. Hence, also maximum values of evapotranspiration from root crops are noted in the end of July (in July the average sum of evapotranspiration in the Wielkopolska Region is $112 \mathrm{~mm}$ ) and remain at a high level until September (Table 5).

Next, the development of meadows depends mostly on the species of grass. However, the development of grass is characterised by high dynamics of achieving next stages of development from growth to heading and to mowing. As a rule, meadows reach their first maturity in June. That is why maximum values of evapotranspiration from meadows are recorded already in June (in the region, the mean value of evapotranspiration in June is about $110 \mathrm{~mm}$ ). Second maturity is reached in August (Table 5).

Annual distribution and monthly values of evapotranspiration of individual biologically active surfaces are in agreement with estimates of other authors. For example, Leśny and

Table 5 Monthly evapotranspiration ( $\mathrm{mm}$ ) for different land-use units in the reference period 1961-1990, based on the MPI-M-REMO model

\begin{tabular}{|c|c|c|c|c|c|c|c|c|c|c|c|c|}
\hline & Jan & Feb & Mar & Apr & May & Jun & Jul & Aug & Sep & Oct & Nov & Dec \\
\hline Water bodies & \multirow[t]{8}{*}{7.7} & \multirow[t]{8}{*}{10.3} & 29.3 & 79.4 & 125.1 & 143.2 & 140.3 & 111.1 & 64.7 & 22.7 & \multirow[t]{8}{*}{26.3} & \multirow[t]{8}{*}{14.4} \\
\hline Deciduous forests & & & 25.0 & 51.5 & 101.5 & 120.0 & 118.4 & 94.6 & 55.9 & 20.1 & & \\
\hline Coniferous forests & & & 26.1 & 64.2 & 114.2 & 129.9 & 128.1 & 103.0 & 61.7 & 21.8 & & \\
\hline Cereal crops & & & 24.3 & 52.0 & 91.6 & 110.1 & 106.7 & 54.4 & 38.1 & 16.4 & & \\
\hline Root crops & & & 23.8 & 43.1 & 55.6 & 89.8 & 112.3 & 89.5 & 52.4 & 17.2 & & \\
\hline Meadows & & & 25.2 & 57.0 & 72.8 & 107.3 & 75.3 & 63.7 & 34.3 & 13.4 & & \\
\hline Wastelands & & & 23.8 & 42.8 & 55.0 & 61.3 & 61.0 & 53.9 & 37.7 & 15.9 & & \\
\hline Urban areas & & & 20.5 & 33.2 & 44.5 & 50.2 & 50.0 & 43.3 & 28.9 & 9.1 & & \\
\hline
\end{tabular}


Table 6 The changes of the monthly sum of areal evapotranspiration $(\mathrm{mm})$ in the future (2061-2090), compared to the control period 1961-1990, based on the MPI-M-REMO model

\begin{tabular}{|c|c|c|c|c|c|c|c|c|c|c|c|c|}
\hline & Jan & Feb & Mar & Apr & May & Jun & Jul & Aug & Sep & Oct & Nov & Dec \\
\hline Water bodies & 7.3 & 8.1 & 7.0 & 0.7 & 2.0 & 3.6 & 4.1 & 4.6 & 3.3 & 2.3 & 7.2 & 4.8 \\
\hline $\begin{array}{l}\text { Deciduous } \\
\text { forests }\end{array}$ & & & 5.8 & -1.6 & 1.9 & 3.9 & 4.2 & 4.8 & 3.4 & 1.6 & & \\
\hline $\begin{array}{l}\text { Coniferous } \\
\text { forests }\end{array}$ & & & 6.2 & -0.3 & 2.1 & 3.9 & 4.2 & 4.8 & 3.4 & 1.7 & & \\
\hline Cereal crops & & & 6.1 & -0.8 & 1.8 & 3.8 & 3.8 & -0.3 & -0.2 & 0.7 & & \\
\hline Root crops & & & 5.7 & -2.1 & -1.1 & 0.9 & 4.1 & 4.8 & 3.4 & 2.4 & & \\
\hline Meadows & & & 7.1 & 0.7 & 0.4 & 3.5 & 0.7 & 1.6 & -0.2 & 0.5 & & \\
\hline Wastelands & & & 5.7 & -2.1 & -1.1 & -1.5 & -0.5 & -0.3 & -0.3 & 0.3 & & \\
\hline Urban areas & & & 6.2 & -1.4 & -0.7 & -0.9 & -0.1 & 0.3 & 0.3 & 1.0 & & \\
\hline
\end{tabular}

Juszczak (2005a) used the HBM method to calculate the value of evapotranspiration for the deciduous forest and agricultural areas. Monthly values of evapotranspiration of the deciduous forest start from about $65 \mathrm{~mm}$ in April to maximum in July (about $130 \mathrm{~mm}$ ) and then fall down to $65 \mathrm{~mm}$ in September and about $25 \mathrm{~mm}$ in October (compare Table 5). Similarly, very good correlation of received results has been observed in case of root crops and cereal crops. Values of the evaporation in urban areas obtained from this research also broadly agree with results received by other authors. Using the method of eddy covariance, Siedlecki et al. (2012) estimated that monthly values of evaporation in the city of Łódź exceed $50 \mathrm{~mm}$, whereas in the winter period, they are from 3 to $16 \mathrm{~mm}$ (compare Table 5).

The obtained value of winter evaporation corresponds to the recent papers of other researchers. The results of long-term measurements (1951-1970) conducted in Turew (Wielkopolska, Poland) show that values of evaporation in winter (XII-II) are in the range of several millimetres, while the air temperature in these months is close to zero Kędziora and Olejnik (2002).

The MPI-M-REMO model projects increases of areal evapotranspiration from different land-use units for annual values. For individual months, it is not so explicit and additionally depends on land-use units. The highest increases of areal evapotranspiration are projected for winter months, with the maximum in February. In the fully growing season, the highest increases are expected to take place in July and June (for water bodies, forests and cultivations, about $4 \mathrm{~mm}$ monthly). Even higher increases are projected for March (about $7 \mathrm{~mm}$ ). These findings could suggest that the growing season will be extended in the future (Table 6).

The projected increases in March are much higher than those in September. Moreover, for September, a decrease of evapotranspiration is projected for cereal crops and wastelands. At present, in an average year, there is more water in the soil in spring than in the summer and in the autumn; however, "the share" of March evapotranspiration in the annual evaporation from water bodies amounts to about $4 \%$ only, while of September to more than $8 \%$. So, ratio of monthly evaporation in March to September at present amounts to 0.45 as regional average. According to projections of the MPI-M-REMO model, in the future, the areal evaporation in March will be rising, whereas in September, it will be clearly decreasing (Table 6); hence, the ratio will grow.

For different types of land-use units, values of this relation (March to September) in the control period and in the future are collected in Table 7 . In this table, average values for the region are presented, whereas the spatial variability in the region is illustrated on the example of cereal crops in Fig. 7. On this basis, it is possible to conclude that in the future, a share of areal evapotranspiration from winter and spring months in the annual sum will increase, while the contribution of autumn and summer will decrease. A connection with an observed rise of temperature in the colder half year is clear (Graczyk 2013) as well as with changes in the regime of rivers and the water cycle, going towards the reduction of baseflows (Gutry-Korycka and Rotnicka 2003).

\section{Changes of areal evapotranspiration in the region}

Changes of the areal evapotranspiration provided so far have been considered for every individual land-use unit. Here,

Table 7 Ratio of areal March evapotranspiration to areal September evapotranspiration for the control period (1961-1990) and in the future (2061-2090) for different types of land-use units in the Wielkopolska Region

\begin{tabular}{lll}
\hline & Control period & Future \\
\hline Water bodies & 0.42 & 0.50 \\
Deciduous forests & 0.45 & 0.52 \\
Coniferous forests & 0.42 & 0.50 \\
Cereal crops & 0.64 & 0.80 \\
Root crops & 0.45 & 0.53 \\
Meadows & 0.95 & 0.95 \\
Wastelands & 0.63 & 0.79 \\
Urban areas & 0.71 & 0.92 \\
\hline
\end{tabular}



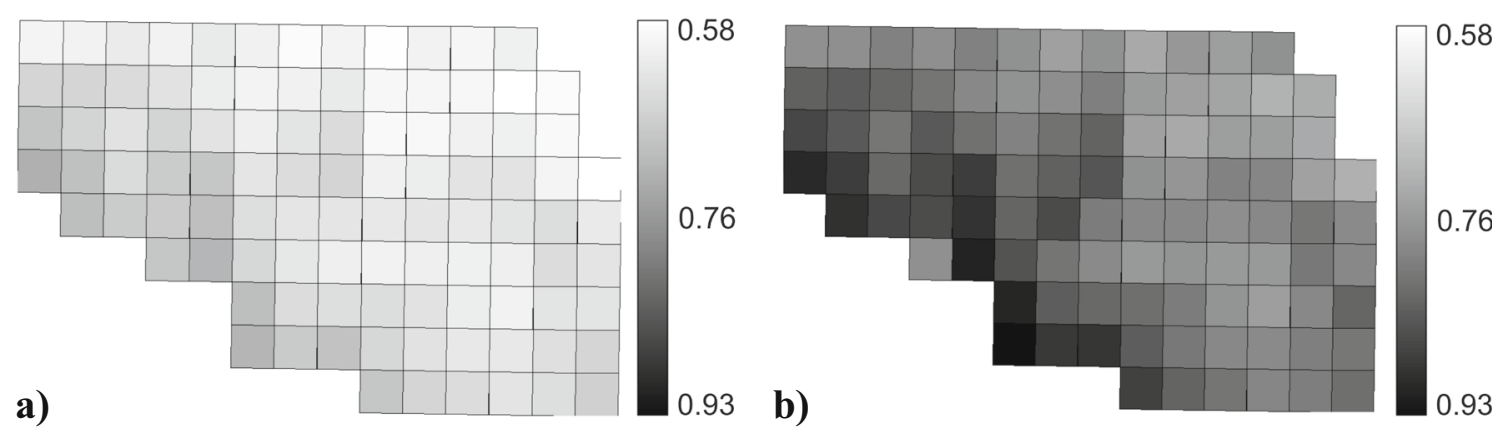

Fig. 7 Ratio of monthly areal evapotranspiration, March to September, a in the control period (1961-1990) and b in the future (2061-2090) for cereal crops

future changes of the evapotranspiration caused solely by a change of climatic condition, without any changes of land use are presented. A total evapotranspiration from each grid-cell area (taking into consideration the share of individual land-use units) has been estimated, based on the MPI-M-REMO model.

The MPI-M-REMO model estimates that in the Wielkopolska Region average annual areal evapotranspiration in all analysed grid-cells currently varies from 538 to $647 \mathrm{~mm}$ (with the average value for the region of $583 \mathrm{~mm}$ ). Projections indicate that in the future horizon of interest (2061-2090) these values will be higher, on average, by $45 \mathrm{~mm}$ (Table 8 ). Other researchers, Jankowiak and Kędziora (2009), estimated the current average field evaporation for the Wielkopolska Region on about $415 \mathrm{~mm}$ in the warm period (AprilSeptember) and $110 \mathrm{~mm}$ in the cool period, that is annually on the level of $525 \mathrm{~mm}$.

Table 8 The mean annual and monthly sums of areal evapotranspiration $(\mathrm{mm})$ in grid-cells for the control period (19611990), in the future (2061-2090) and the changes of areal evapotranspiration $(\mathrm{mm})$ future vs present, based on the MPI-M-REMO model

\begin{tabular}{llll}
\hline & Control period & Future & Difference \\
\hline Jan & 7.7 & 15.0 & 7.3 \\
Feb & 10.3 & 18.5 & 8.1 \\
Mar & 24.6 & 30.7 & 6.1 \\
Apr & 52.8 & 51.8 & -0.9 \\
May & 89.7 & 91.0 & 1.3 \\
Jun & 110.5 & 113.7 & 3.3 \\
Jul & 109.2 & 112.9 & 3.7 \\
Aug & 73.4 & 75.5 & 2.1 \\
Sep & 46.0 & 47.5 & 1.4 \\
Oct & 17.6 & 18.8 & 1.2 \\
Nov & 26.3 & 33.5 & 7.2 \\
Dec & 14.4 & 19.2 & 4.8 \\
Year & 582.5 & 628.1 & 45.6 \\
\hline
\end{tabular}

The spatial distribution of evapotranspiration from the gridcell areas shows that, at present, areal evapotranspiration decreases towards the east, with the lowest values in the northeastern parts and in the central part of the region. Projections of the MPI-M-REMO model indicate the smallest increases of evapotranspiration in the areas where the areal evapotranspiration is the lowest at present. The highest increases are projected for the areas with presently highest evapotranspiration, e.g. the southwestern parts of the region (Fig. 8).

However, it is hard to foresee if land-use changes will (or will not) have taken place by the analysed future period (2061-2090). Therefore, for a randomly chosen grid-cell (line 3, col 7 on Fig. 2), four variants of the change of the land use are considered and the annual areal evapotranspiration is estimated for these new structures of land use.

- Variant 1 assumes an increase in the urbanised areas up to $10 \%$ of the grid-cell area at the expense of areas of cereal crops and meadows.

- Variant 2 assumes an increase in urbanised areas up to $10 \%$ of the grid-cell area and further intensification of agriculture (increase of the root crops area). The area of meadows, waters and forests would be reduced.

- Variant 3 assumes not only a similar increase of urbanised areas but also without farming (fewer cereal and root crops). An increase of meadow areas is also assumed.

- Variant 4, being the most "ecological" one, assumes, in spite of increase of urbanised areas, as in previous cases, some increase of the afforestation and reduction of the farming.

Calculated values of annual and monthly areal evapotranspiration for hypothetical variants are presented in Table 9. A conclusion from Table 9 is that projected climate changes are a bit more important for the value of areal evapotranspiration (higher differences of the values of areal evapotranspiration between the present and the future - annually $43 \mathrm{~mm}$ for a selected grid-cell) than differences triggered by the change of land-use structure. However, magnitudes of these changes are also of no small importance, and between analysed 


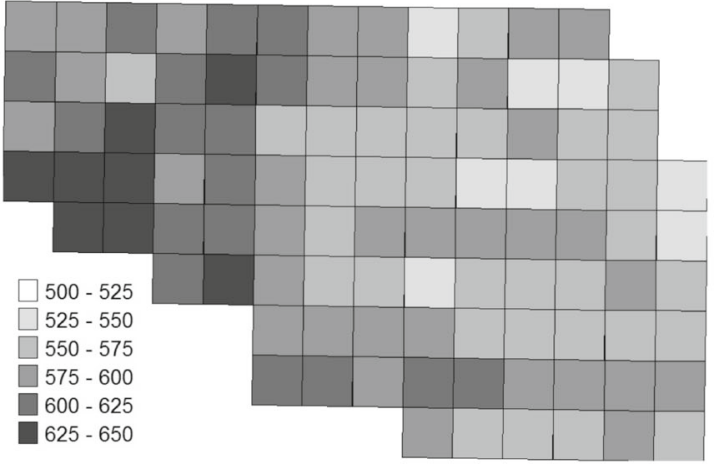

a)

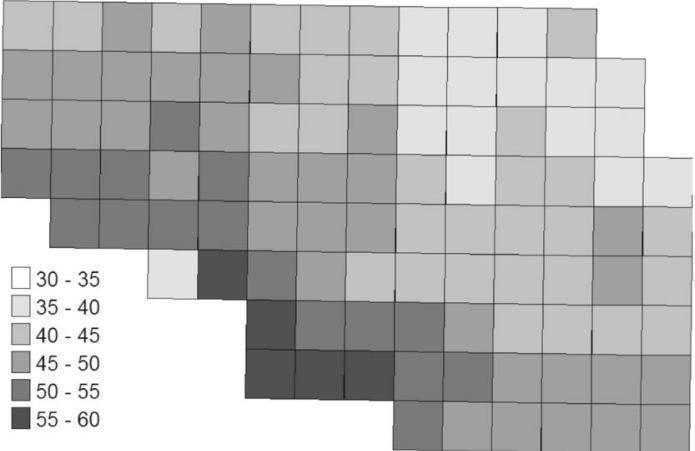

b)

Fig. 8 The annual areal evapotranspiration (mm) for every grid-cell (under assumption of the present land-use structure) a in the control period (19611990) and $\mathbf{b}$ the increases of the evapotranspiration (mm) in the future (2061-2090)

variants, they amounted to $38 \mathrm{~mm}$ annually. It should be added here that control over land-use structure enables modification of the distribution of the areal evapotranspiration within 1 year, which would considerably improve water conditions of the area.

\section{Conclusions}

According to the results obtained with the help of the RCMs applied in this research, it seems that future changes in climate conditions in the Wielkopolska Region will not be very dramatic. Projections for the future, based on the MPI-M-REMO model, indicate that the regional average of increases of the annual sum of areal evapotranspiration (connected mainly with an increase of air temperature) is equal to $45 \mathrm{~mm}$, with the biggest changes during winter. In the growing season, the highest increases are expected to appear in March (hence, the growing season is likely to be prolonged in the future), July and June. The projected increases are much higher than the ones in September. It seems that in the future a share of the areal evapotranspiration from winter and spring months in the annual sum will increase, while the contribution of autumn and summer will decrease.

However, values of the areal evapotranspiration, its seasonal distribution and expected changes in the future are land unit dependent. That is why this paper takes into account eight land-use units. It is necessary to underline that they affect not only areal evapotranspiration: amount of the available energy (temperature), humidity or the state of thermodynamic

Table 9 The mean annual and monthly sums of areal evapotranspiration (mm) in random selected grid-cell for the control period (1961-1990) and for hypothetical variants of land-use changes in the future (2061-2090), based on the MPI-M-REMO model

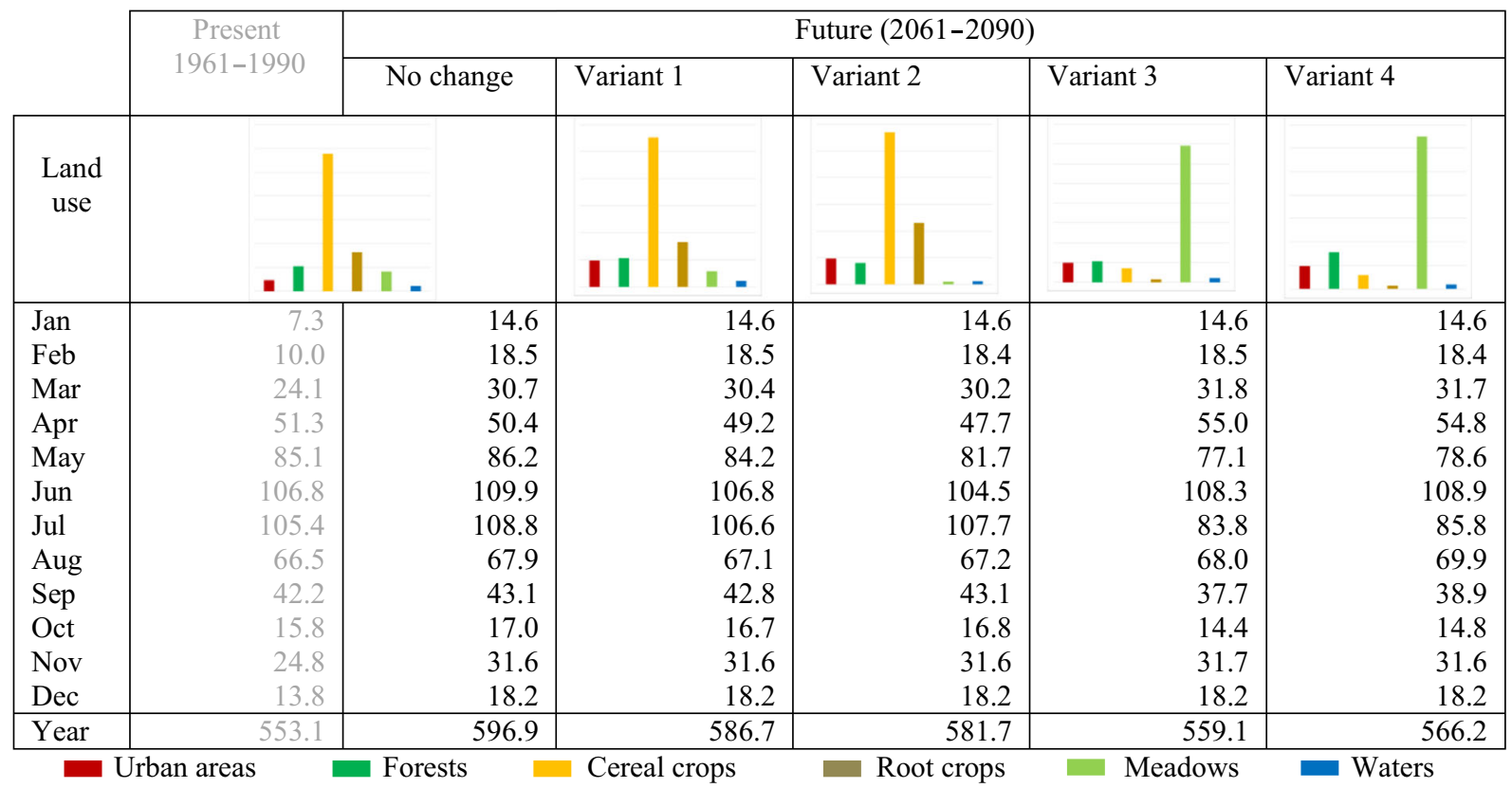


equilibrium of the atmosphere but also the type of land-use cover and the plant-development state.

At present, in an average year, there is more water in the soil in spring than in summer and autumn. The development of winter crops peaks in spring and early summer and for the root plants in summer and early autumn. So, for example, if winter crops dominate in the landscape structure, a higher evapotranspiration is observed in spring and early summer. If a share of plants with extended growth such as root crops and fruit trees in orchards (similarly to deciduous forest) in the landscape increases, evapotranspiration occurs more evenly in the entire growing season. However, projected climate changes are a more important factor influencing the value of areal evapotranspiration in the future than changes of land-use structure.

The universally projected warming will result in changes in all elements of the water balance, including the areal evapotranspiration. It will have impact on living elements of the natural environment, but plants will also affect elements of the climate system to some extent through a feedback coupling. Even though projected changes in evapotranspiration are not strong enough to force changes in the land-use structure, there is still opportunity to modify the landscape in a way that will advantageously change elements of the water balance (e.g. evapotranspiration) and in this way to improve the water balance in the region.

Open Access This article is distributed under the terms of the Creative Commons Attribution 4.0 International License (http:// creativecommons.org/licenses/by/4.0/), which permits unrestricted use, distribution, and reproduction in any medium, provided you give appropriate credit to the original author(s) and the source, provide a link to the Creative Commons license, and indicate if changes were made.

\section{References}

Barella-Ortiz A, Polcher J, Tuzet A, Laval K (2013) Potential evaporation estimation through an unstressed surface energy balance and its sensitivity to climate change. Hydrol Earth Syst Sci 17(11):46254639

Czarnecka M, Koźmiński C, Michalska B (2009) Climatic risks for plant cultivation in Poland. Acta Agrophysica, Rozprawy i Monografie 169(1):78-96

EEA (2000) European Environmental Agency data service., CLC2000 data: http://dataservice.eea.eu.int/

Eulenstein F, Leśny J, Chojnicki BH, Kędziora A, Olejnik J (2005) Analysis of the interrelation between the heat balance structure and the type of plant covered and weather conditions. Int Agrophysics 19(2):125-130

Filimonova M, Trubetskova M (2005) Calculation of evaporation from the Caspian Sea surface. 9th ISSH SEMINAR on Stochastic Hydraulics, De Vereeniging, Nijmegen, The Netherlands 23-24 May, 2005

Graczyk D (2013) Warunki temperaturowe Polski w zmieniającym się klimacie Europy. Praca doktorska. (Thermal conditions of Poland in the changing climate. PhD dissertation), typescript. Biblioteka Główna UP w Poznaniu

Grelle A, Lindroth A, Molder M (1999) Seasonal variation of boreal forest surface conductance and evaporation. Agric For Meteorol 98/99:563-578

Gustafsson D, Lewan E, Jansson P-E (2004) Modeling water and heat balance of the boreal landscape - comparison of forest and arable land in Scandinavia. J App Meteorol 43:1750-1767

Gutry-Korycka M, Rotnicka J (2003) Ustrój hydrologiczny rzek w świetle scenariuszy zmian globalnych klimatu (The hydrological regime of rivers in the light of global climate change scenarios). $\mathrm{Pr}$ Stud Geogr WGiSR UW 31:61-77

Huntington TG (2006) Evidence for intensification of the global water cycle: review and synthesis. J Hydrol 319:83-95

IPCC (2000) Emissions scenarios. In: Nakićenović N, Swart R (eds) Special report on emissions scenarios: a special report of Working Group III of the Intergovernmental Panel on Climate Change. Cambridge University Press, UK, p 570

IPCC (2013) In: Stocker TF, Qin D, Plattner G-K, Tignor M, Allen SK, Boschung J, Nauels A, Xia Y, Bex V, Midgley PM (eds) Climate change 2013. The physical science basis. Contribution of Working Group I to the Fifth Assessment Report of the Intergovernmental Panel on Climate Change. Cambridge University Press, Cambridge, United Kingdom and New York, NY, USA, p 1535

Ив анов (Ivanov) НН (1954) Об определении величин испаряемости. (About determination of evapotranspiration). Известия Всес Геогр Общества, Т 86(2):189-195

Jankowiak J, Kędziora A (2009) Globalne zmiany klimatu i ich wpływ na rolnictwo w Polsce (Global climate changes and their influence on agriculture). In: Zegara JS (ed) Z badań nad rolnictwem społecznie zrównoważonym (From the research on socially balanced agriculture). IERiGZ-PIB, Warszawa, p 101

Jokiel P (2004) Zasoby wodne środkowej Polski na progu XXI wieku (Water resources of central Poland on the threshold of the twentyfirst century). Wyd. UL, Łodź

Kar G, Kumar A (2007) Surface energy fluxes and crop water stress index in groundnut under irrigated ecosystem. Agric Forest Meteorol 146(1-2):94-106

Kędziora A (1999) Podstawy agrometeorologii (Basics of agrometeorology). PWRiL, Poznań

Kędziora A, Olejnik J (2002) Water balance in agricultural landscape and options for its management by change of plant cover structure of landscape. In: Ryszkowski L (ed) Landscape ecology in agroecosystems management. CRC Press, Boca Raton, London, New York, Washington D.C., pp 57-110

Kędziora A, Olejnik J, Kapuściński J (1989) Impact of landscape structure on heat and water balance. Ecol Int Bull 17:1-17

Leśny J (1998) Analiza wpływu pokrywy roślinnej na strukturę bilansu cieplnego powierzchni czynnej. Praca doktorska (Analysis of the impact of vegetation cover on the heat balance structure of the active surface. PhD thesis) (typescript). Biblioteka Główna UP w Poznaniu, $106 \mathrm{pp}$

Leśny J (2011) Bilans cieplny powierzchni czynnej wybranych upraw w Wielkopolsce (Heat balance of the active surface of selected crops in the Wielkopolska Region). Wyd. UP Pozn., Zesz. Nauk., 429

Leśny J, Juszczak R. (2004) Ewapotranspiracja i bilans wodny zlewni Rowu Wyskoć (Evapotranspiration and water balance of the Rów Wyskoć catchment). Zeszyty Naukowe AR Wrocław, Inżynieria Środowiska XIII, nr 502

Leśny J, Juszczak R (2005a) Klimatyczny bilans wodny terenów rolniczych i leśnych (Climatic water balance for agricultural and forest areas). Water-Environment-Rural Areas. IMUZ Falenty 5(2):53-65

Leśny J, Juszczak R (2005b) Oszacowanie ewapotranspiracji terenów znajdujących się w strefie bezpośredniego oddziaływania małych zbiorników wodnych krajobrazu rolniczego (Evaluation of evapotranspiration of areas located within the zone of direct impact of 
small water reservoirs in agricultural landscape). Acta Agrophysica 6(1):161-174

Minderlein S, Menzel L (2015) Evapotranspiration and energy balance dynamics of a semi-arid mountainous steppe and shrubland site in Northern Mongolia. Environ Earth Sci 73(2):593-609

Mo X, Liu S (2001) Simulating evapotranspiration and photosynthesis of winter wheat over the growing season. Agric For Meteor 109:203222

Musiał E, Kamińska J, Gąsiorek E (2007) Zmiany w strukturze bilansu cieplnego i klimatycznego bilansu wodnego dla lasu iglastego (Changes in the structure of heat balance and climatic water balance of the coniferous forest). Water-environment-rural areas. IMUZ Falenty $2 \mathrm{~b}(21): 111-119$

Olejnik J (1996) Modelowe badania struktury bilansu cieplnego i wodnego zlewni w obecnych i przyszłych warunkach klimatycznych. (Model studies on the structure of the heat and water balance for catchment in present and future climate conditions). Rocz. AR Pozn., z.266, rozprawa hab.

Olejnik J, Kędziora A (1991) A model for heat and water balance estimation and its application to land use and climate variation. Earth Surface Processes Landforms 16:601-617

Olejnik J, Leśny J, Eulenstein F, Kędziora A (1999) Ekstremalne wartości składników bilansu cieplnego agroekosystemow w różnych warunkach klimatycznych (Extreme values of the heat balance components in agro-ecosystems in different climatic conditions). Fol. Univ. Agric. Stetin. 202 Agriculture, (79): 179-184
Olejnik J, Leśny J, Kędziora A (2000) The method of estimation of Bowen ratio area distribution by parameterisation based on meteorological and land-use data. Pr Geog UJ 108:407-413

Persson G (1997) Comparison of simulated water balance for willow, spruce, grass ley and barley. Nord Hydrol 28:85-98

Rahimikhoob A (2010) Estimation of evapotranspiration based on only air temperature data using artificial neural networks for a subtropical climate in Iran. Theor Appl Climatol 101:83-91

Siedlecki M, Fortuniak K, Pawlak W (2012) Porównanie wybranych metod określania parowania w Łodzi (The comparison of selected methods of determining evaporation in Łódź). Przegląd Geofiz 2: 211-221

Szwed M, Karg G, Pińskwar I, Radziejewski M, Graczyk D, Kędziora A, Kundzewicz ZW (2010) Climate change and its effect on agriculture, water resources and human health sectors in Poland. Nat Hazards Earth Syst Sci 10:1725-1737. doi:10.5194/nhess-101725-2010

UStat Poznań (2013) Rocznik Statystyczny Województwa Wielkopolskiego 2013. (Statistical Yearbook of the Wielkopolska Voivodship 2013) Urzą Statystyczny w Poznaniu

Van der Linden P, Mitchell JFB (eds.) (2009) ENSEMBLES: climate change and its impacts: summary of research and results from the ENSEMBLES project. Met Office Hadley Centre, FitzRoy Road, Exeter EX1 3PB, UK. 160 pp

Wetherald RT, Manabe S (2002) Simulation of hydrologic changes associated with global warming. J Geophys Res 107(D19):4379. doi:10.1029/2001JD001195 